\title{
New Record of Hippolytid Shrimp Lebbeus grandimana (Crustacea: Decapoda: Caridea) from Korean Waters
}

\author{
Jung Nyun Kim ${ }^{1, *}$, Sang Chul Yoon ${ }^{2}$, Jung Hwa Choi ${ }^{1}$, Taeg Yun Oh${ }^{1}$, \\ Kangseok Hwang ${ }^{1}$, Jong Bin Kim ${ }^{1}$ and Kwang Ho Choi ${ }^{1}$ \\ ${ }^{1}$ Fisheries Resources Management Division, National Fisheries Research and \\ Development Institute, Busan 609-705, Korea \\ ${ }^{2}$ Fisheries Resources and Environment Division, East Sea Fisheries Research Institute, \\ National Fisheries Research and Development Institute, Gangwon 210-861, Korea
}

\begin{abstract}
A hippolytid shrimp, Lebbeus grandimana, is described from the southern part of the East Sea and this is the first record of the species in Korea. The genus Lebbeus of the family Hippolytidae currently comprises four species in Korea. A key to identify the four species of the genus Lebbeus from Korean waters is provided.
\end{abstract}

Keywords: Lebbeus grandimana, Hippolytidae, Caridea, Decapoda, Crustacea, Korea, new record

\section{INTRODUCTION}

The hippolytid genus Lebbeus currently contains 52 species in the world (Ahyong, 2009, 2010; Komai and Collins, 2009; McCallum and Poore, 2010), of which only three species have been reported in Korean waters (Kim and Kim, 1997; Cha et al., 2001; Kim et al., 2007). During the taxonomic survey of the decapod crustaceans in the Korean waters, a hippolytid species, Lebbeus grandimana (Brashnikov, 1907), was newly collected from off Busan, East Sea by the bottom otter trawling. L. grandimana is distributed in the northern North Pacific from the coast of Canada, the Bering Sea, and the Sea of Okhotsk to the East Sea (Hayashi, 1992).

A morphological description and both illustrations and color photographs are provided. Postorbital carapace length (CL) is used as a standard length of the specimens. Terminology was mainly followed that of Hayashi (1992). Specimens examined have been deposited in the Fisheries Resource Research Department, National Fisheries Research and Development Institute (NFRDI).

\section{SYSTEMATIC ACCOUNTS}

Family Hippolytidae Bate, 1888

1 * Lebbeus grandimana (Brashnikov, 1907)

(Figs. 1, 3A)

Hetairus grandimana Brashnikov, 1907, p. 152, fig. 18 [type

*To whom correspondence should be addressed

Tel: 82-51-720-2331, Fax: 82-51-720-2337

E-mail: crangonk@nfrdi.go.kr locality: Kamchatka, Okhotsk Sea, East Sea, 16-100 m]; Derjugin and Kobjakova, 1935, pp. 112, 142; Kobjakova, 1936, p. 222; 1937, p. 108; Makarov, 1941, p. 123, figs. 7 , 8.

Lebbeus grandimana: Vinogradov, 1950, p. 205, pl. 13, fig. 48; Hayashi, 1992, p. 119.

Lebbeus grandimanus: Holthuis, 1947, p. 9; Butler, 1980, p. 178, 2 unnumbered figs.; Wicksten and Mendez, 1982, pp. $117,118$.

Material examined. 1 우 (CL $11.9 \mathrm{~mm}), 3$ ovig. 우 우 (CL 11.7-11.8 mm), off Busan (35 $\left.15.64^{\prime} \mathrm{N} 129^{\circ} 44.14^{\prime} \mathrm{E}\right) 24$ Nov. 2009 (S.C. Yoon, NFRDI), by otter trawl at $142 \mathrm{~m}$, in depth. Description. Body of moderate size. Rostrum (Fig. 1A) straight, 0.6 times as long as carapace, falling short of distal margin of antennular peduncle, knifelike, with 5 teeth on dorsal margin, including 2 teeth on carapace, ventral margin with tooth distally. Carapace (Fig. 1A) not carinate on middorsal line; supraorbital spine well developed without notch; antennal spine moderately developed; pterygostomial spine weak. Abdomen (Fig. 1B) smooth, pleura of first four somites rounded, those of fifth and sixth somites pointed posteriorly. Telson (Fig. 1C) with 3 pairs of dorsal spines, distal margin with 2 pairs of spines. Antennular peduncle (Fig. 1D) with marginal spine on each segment; stylocerite slightly falling short of distal margin of second segment of antennular peduncle. Third maxilliped (Fig. 1E) with 13 mesial and 3 apical spinules on distal segment. Third to fifth pereopods (Fig. 1F) with 2, 2 or 3, 3 or 4 spines on each merus, respectively. Epipods on first and second pereopods. Eyed eggs $1.14-1.36 \times 1.57-1.79 \mathrm{~mm}$ in diameter.

$1 *$ 각시가시배새우(신칭) 


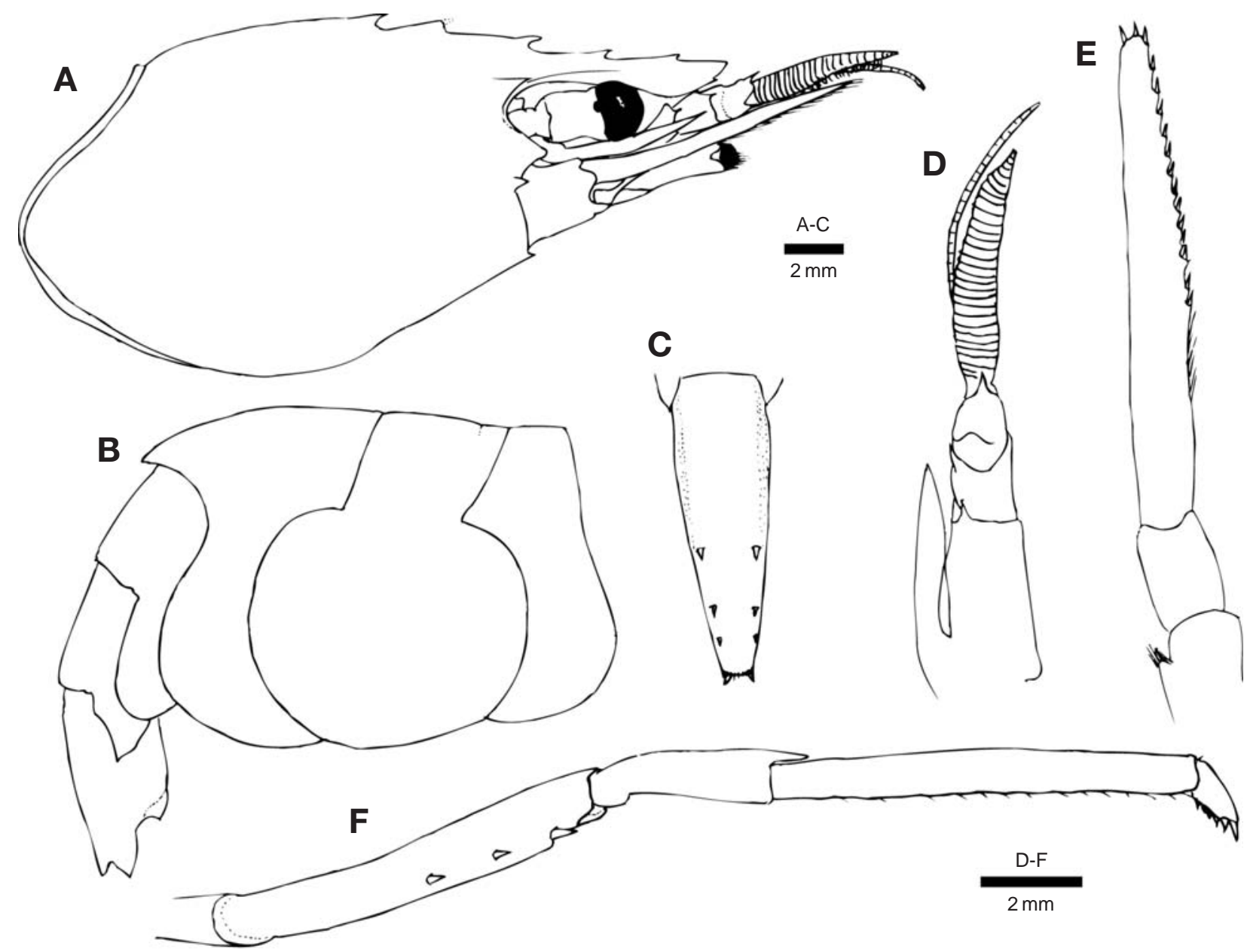

Fig. 1. Lebbeus grandimana (Brashnikov, 1907) from off Busan. $A, B, D-F$, ovigerous female (CL 11.8 mm); C, ovigerous female (CL $11.7 \mathrm{~mm}$ ). A, carapace and cephalic appendages, lateral; B, abdomen, lateral; C, telson, dorsal; D, left antennule, dorsal; E, distal two segments of right third maxilliped, ventral; $F$, right fourth pereopod, lateral.

Coloration. Body pale milkish with 6 main bands which extending over dorsal and lateral surface as follows: 2 white and red on carapace, one just posterior to orbit and across anterior dorsal spine, other at about posterior one-sixth of carapace; one on each second, third, and fifth abdominal somites; one at joint of sixth somite and telson, that extends posteriorly along lateral margin of outer uropod; distal part of telson, distal margins of both uropods, eyestalk, and outer margin of scaphocerite also yellow and red. Four light blue solid or interrupted transverse lines present: one just ventral part of anterior dorsal spine on carapace; one on each of first, third, and fourth abdominal somites. Third maxilliped, pereopods, and flagella of antennule mainly yellow (Fig. 2).

Distribution. Northern North Pacific from the coast of Canada, Bering Sea, Okhotsk Sea to the East Sea and Pacific coast of northern Japan; 15-250 m deep (Hayashi, 1992).
Remarks. Komai et al. (2004) summarized a grouping of species within the genus Lebbeus based on the number of pereopodal epipods. Lebbeus grandimana belongs to the group of two Korean species, L. polaris (Sabine, 1824) and L. unalaskensis (Rathbun, 1902), characterized by epipods on the first two pereopods. The present species is distinguished from these two species by having the posteriorly rounded pleuron of the fourth abdominal somite and the distal segment of the third maxilliped with a series of spinules on the mesial margin. In L. polaris and L. unalaskensis, the pleuron of the fourth abdominal somite is pointed posteriorly and the distal segment of the third maxilliped is unarmed except for some apical spinules.

\section{Key to the four species of the genus Lebbeus in the Korean waters}

1. Epipod present on first three pereopods 

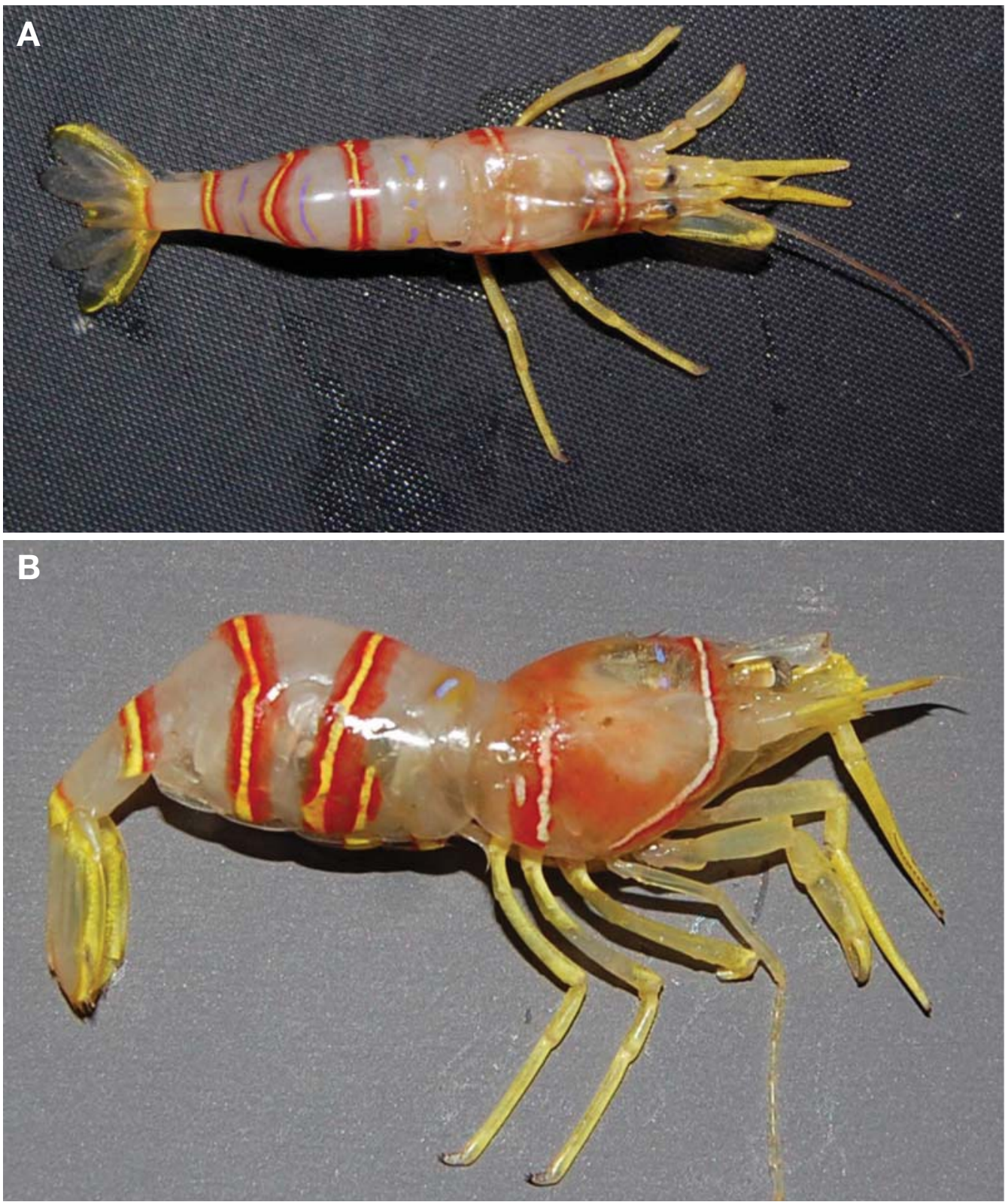

Fig. 2. Lebbeus grandimana (Brashnikov, 1907) from off Busan. A, ovigerous female (CL $11.8 \mathrm{~mm})$, dorsal; $B$, female (CL $11.9 \mathrm{~mm})$, lateral.

\section{L. groenlandicus}

- Epipod on first two pereopods only

2. Pleuron of fourth abdominal somite rounded posteriorly. Distal segment of third maxilliped with a series of spinules on mesial margin L. grandimana

- Pleuron of fourth somite pointed posteriorly. Distal segment of third maxilliped unarmed except for some apical spinules ….............................................. 3

3. Rostrum longer than carapace, reaching beyond antennal scale L. unalaskensis

- Rostrum as long as carapace, extending to distal margin of antennal scale L. polaris

\section{ACKNOWLEDGEMENTS}

This work was funded by the National Fisheries Research and Development Institute (RP-2010-FR-035). 


\section{REFERENCES}

Ahyong, S.T., 2009. New species and new records of hydrothermal vent shrimps from New Zealand (Caridea: Alvinocarididae, Hippolytidae). Crustaceana, 82(7): 775-794.

Ahyong, S.T., 2010. New species and new records of Caridea (Hippolytidae: Pasiphaeidae) from New Zealand. Zootaxa, 2372: 341-357.

Brashnikov, V., 1907. Materiali po fauni Russkikh vostochnikh morei, sovrannie shkhnoju "Storoz" vi 1899-1902 gg. [Materials on the fauna of Russian Eastern Sea collected by the schooner "Storoz" during the year 1899-1902]. Zapiski Imperatorskoi Akademii Nauki, po phiziki-matematichekomu otdilenileniju, 20: 1-185.

Butler, T.H., 1980. Shrimps of the Pacific coast of Canada. Can. Bull. Fish. Aquat. Sci., 202: 1-280.

Cha, H.K., J.U. Lee, C.S. Park, C.I. Baik, S.Y. Hong, J.H. Park, D.W. Lee, Y.M. Choi, K. Hwang, Z.G. Kim, K.H. Choi, H. Sohn, M.H. Sohn, D.H. Kim and J.H. Choi, 2001. Shrimps of the Korean Waters. National Fisheries Research and Development Institute, Busan, pp. 1-188.

Derjugin, K.M. and Z.I. Kobjakova, 1935. Zur Decapodenfauna des Japanischen Meeres. Zoologicher Anzeiger, 112: 141-147.

Hayashi, K., 1992. Studies on the hippolytid shrimps from Japan-VIII. The genus Lebbeus White. J. Shimonoseki Univ. Fish., 40: 107-138.

Holthuis, L.B., 1947. The Decapoda of the Siboga Expedition. Part IX. The Hippolytidae and Rhynchocinetidae collected by the Siboga and Snellius Expeditions with remarks on other species. Siboga Exped. Monogr., 39a ${ }^{8}$ : 1-100.

Kim, H.S. and W. Kim, 1997. Order Decapoda. In: List of animals in Korea (excluding insects) (Eds., The Korean Society of Systematic Zoology). pp. 212-223. Academy Publ. Co., Seoul.

Kim, J.N., J.H. Choi, B.G. Hong, K. Hwang and Y.Y. Chun, 2007. Two hippolytid shrimps (Crustacea: Decapoda: Caridea) from the deepwater of the East Sea, Korea. Korean J. Syst. Zool., 23: 199-203.

Kobjakova, Z.I., 1936. Zoogeographicheskii obzor fauny Decapoda Okhotkogo i Japonskogo morei. [Zoogeographical review of the Decapoda fauna from the Okhotsk and Japan- ese Seas]. Trudy Leningrad Obshestva Estestvoispitatelei, 65: 185-228.

Kobjakova, Z.I., 1937. Desyatinogie raki (Decapoda) Okhotskogo i Japonskogo morei. [Systematic review of the Decapoda of the Okhotsk and Japanese seas]. Uchenie Zapiski Leningrad Universtaet, 15: 93-154.

Komai, T. and P. Collins, 2009. Two species of caridean shrimps (Decapoda: Hippolytidae and Nematocarcinidae) newly recorded from hydrothermal vents on the Manus Basin, southwestern Pacific. Crust. Res., 38: 28-41.

Komai, T., K. Hayashi and H. Kohtsuka, 2004. Two new species of the shrimp genus Lebbeus White from the Sea of Japan, with redescription of Lebbeus kuboi Hayashi (Decapoda: Caridea: Hippolytidae). Crust. Res., 33: 103-125.

Makarov, V.V., 1941. Fauna Decapoda Beringova i Chukogskogo morei. [The decapod Crustacea of the Bering and Chukchees Seas]. Issledovanija dalinevostichnikh morei SSSR, 1: 111-163.

McCallum, A.W. and G.C.B. Poore, 2010. Two crested and colourful new species of Lebbeus (Crustacea: Caridea: Hippolytidae) from the continental margin of western Australia. Zootaxa, 2372: 126-137.

Rathbun, M.J., 1902. Japanese stalk-eyed crustaceans. Proc. U.S. Nat. Mus., 26: 23-55.

Sabine, J., 1824. Invertebrate animals. In: Journal of a voyage for the discovery of a north-west passage from the Atlantic to the Pacific: performed in the years 1819-1820 in His Majesty's ships Heclaand Griper, under the orders of William Edward Parry, R.N., F.R.S. and commander of the expedition. Appendix X. Natural History. John Murray, London, pp. 219-239.

Vinogradov, L.G., 1950. Opredeliteli krevetok, rakov, i krabov dalinego Vostoka. [Classifcaion of shrimps, prawns, and crabs from Far East]. Izvestija Tikhookeanskogo NauchnoIssledovatel'skogo Instituta Rybnogo Khozjaystva i Okeanografiyi, 33: 179-358.

Wicksten, M.K. and M. Mendez, 1982. New records and new species of the genus Lebbeus (Caridea: Hippolytidae) in the eastern Pacific Ocean. Bull. Southern California Acad. Sci., 81: 106-120.

Received September 29, 2010 Accepted November 12, 2010 